\title{
Electrical Performances of Lithium-Ion Coin Cell Based on Reduced Graphene Oxide (RGO)
}

\author{
Zainul Arifin Imam Supardi ${ }^{1}$, Munasir, Dwi Astuti \\ Ningsih \\ Physics Department \\ Universitas Negeri Surabaya \\ Surabaya, Indonesia \\ ${ }^{1}$ zainularifin@unesa.ac.id
}

\author{
Bambang Prihandoko \\ Physics Research Center \\ Indonesian Institute of Science \\ Jakarta, Indonesia
}

\begin{abstract}
Recently many portable devices need electrical energy which instant and high capacity. Lithium-ion battery is one of very popular as mobile electrical energy source for them. This study focused to elaborate the electrical performances of reduced graphene. They were electrical conductivity, cycle performance of charge-discharge, and specific capacity. Doctor blade technique was used to produce the anode. Vacuum technique was used to assembly Lithium-Ion Coin Cell. Electrochemical Impedance Spectroscopy and Cyclic Voltammetry were used to measure the electrical performances of coin cell. The results showed that electrical conductivity value was $8 \times 10^{-5} \mathrm{~S} / \mathrm{cm}$, and the specific capacity value was $400 \mathrm{mAHr} / \mathrm{g}$. So, this study has shown a prospective application in the future to produced commercially lithium-ion coin cells.
\end{abstract}

Keywords-Reduced Graphene Oxide (rGO), Anode, LithiumIon Coin Cell, and Doctor Blade Technique

\section{INTRODUCTION}

Recently many devices need mobile electrical energy sources for supporting and help our life easily. They are calculator, mobile phone, smart watch, digital camera, laptop, and immediately electric vehicles and hybrid vehicles. The main problem is to get electrical energy sources which properties high energy density, higher output power, fast charging, support green environmental principle, small and lightweight in size, and durable [1]. For this reason, Lithium Ion Battery (LIB) is the promising electrical energy sources for suppoting mobile compact energy.

One of the important prototype of LIB is coin cell. It can be assembled from reduced Graphene Oxide/Copper $(\mathrm{rGO} / \mathrm{Cu})$ anode, lithium foil cathode, polypropylene separator, and $\mathrm{PF}_{6}$ electrolyte [2]. They have many advantages to develop Lithium-Ion (LI)-Coin Cell because it has good conductivity, higher energy capacity, easy and cheaper in fabricating, and durable.

Various popular methods are used to prepare battery anode, i.e. solid state method, hydrothermal route, solvothermal process, electrospinning deposition, microwavehydrothermal method, and sol gel method have been proposed by many researchers [3-7]. In this work solvothermal route was used to prepare slury material for anode. Doctor blade technique and solid state rection method were employed to prepare $\mathrm{rGO} / \mathrm{Cu}$ composite. Moreover, the effect of rGO to the electrical performances of LI-Coin Cell are also carefully investigated.

\section{EXPERIMENTAL AND MEASUREMENTS}

LI-Coin Cell formation contained three stages, i.e. preparation of components, assembly process, and measurement of electrical performance. For detailing each stage is explained as follows.

\section{A. Preparation Components LI-Coin Cell}

Main Components of LI-Coin consist of anode, cathode, separator, electrolyte, and coin jacket. Anode $\mathrm{rGO} / \mathrm{Cu}$ was prepared through three stages, i.e. formation of: (1) rGO powder, (2) slurry, and (3) anode composite. It was prepared from coconut shell using the special treatment [8]. Slurry was prepared from rGO powder, polyvinylidene difluoride (PVDF), and acetylene black (AB) with percentage ratio $85: 10: 5$. They were dissolved and Stirred $\left(100 \mathrm{rpm}\right.$ and $\left.80^{\circ} \mathrm{C}\right)$ in N,N-Dimethylacetamide (N,N-DMAC). The slurry was superimposed to copper foil using doctor blade equipment with tape casting method. Then it was dried and cut which diameter $16 \mathrm{~mm}$. Standard Lithium foil was used as cathode material (diameter $16 \mathrm{~mm}$ ) and polypropylene as separator material with diameter size in $199 \mathrm{~mm}$. Further, electrolyte commercial $\mathrm{PF}_{6}$-EC:DEC was completed as LI-Coin Cell components.

\section{B. Assembly Process of LI-Coin Cell}

All of components above were assembled to be a coin cell in a glove box with argon environment with the structure: anode-separator-electrolyte-anode. These components were protected by metal jacket.

\section{Mesurement of Electrical Performance}

Electrochemical Impedance Spectroscopic (EIS) measurements were carried out with the frequency range $0.5 \mathrm{~Hz}$ to 20 $\mathrm{kHz}$ using the across voltage 0.1 volt. Cyclic Voltammetry (CV) was used to measure the redox cyclic of the process of intercalation/deintercalation of Lithium ion. Cyclic voltammo- 
gram curves were recorded from 0.0 to $3.0 \mathrm{~V}$ with a scan rate of $0.1 \mathrm{mV} / \mathrm{s}$. Automatic Battery Cycler WBCS3000 Version 3.2 was used to measure Charge-Discharge (CD) with $0.1 \mathrm{C}$ rate.

\section{RESULTS AND DISCUSSION}

\section{A. Results of EIS Measurement}

First, impedance confirmed through EIS measurement. It measured values of real $(Z)$ and imaginary (Z') impedance as displayed at Fig.1. Semi-circle curve represented the electrolyte resistance $\left(\mathrm{R}_{\mathrm{e}}\right)$ that arise as consequence of electrochemical reaction between electrolyte and surface of active material. Straight line represented diffusion process of lithium ion into bulk electrode material. It as a reference for electrode's performance to save lithium ion.

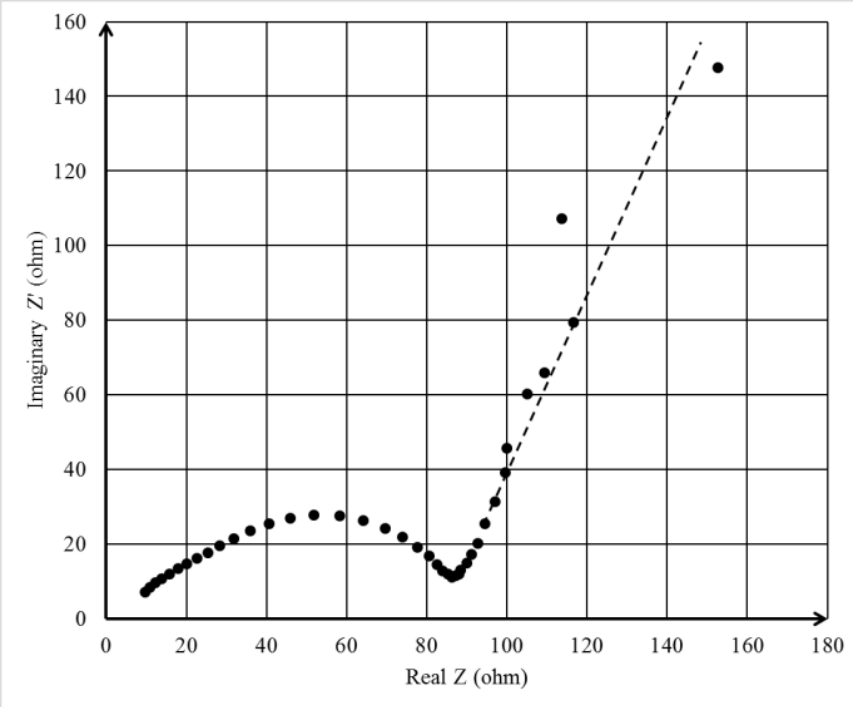

Fig. 1. Nyquist Plot of Coin Cell

Figure 1 and 2 show the profile of impedance of coin cell which electrical conductivity $(\sigma)$ value is $8.2 \times 10^{-5} \mathrm{~S} / \mathrm{cm}$. It is enough to meet the requirement as coin cell [9].

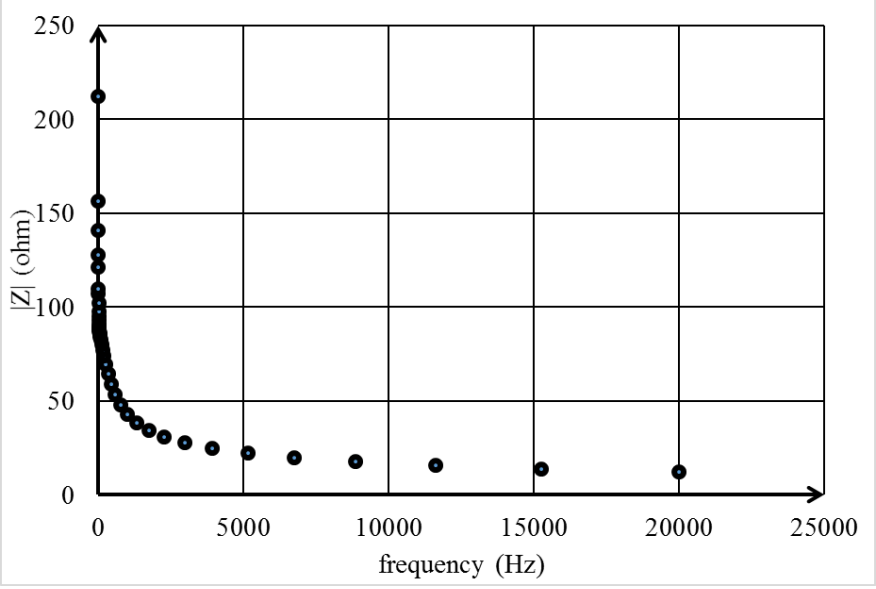

Fig. 2. Bode Plot of Coin Cell

\section{B. Results of CV Measurement}

Figure 3 shows the voltammogram of $\mathrm{CV}$ measurement that describe the peak value of anode and cathode voltage. In this measurement the both peaks did not appear sharply. In the first cycle measurement has the different voltage 1.0 volt and 0.8 volt for next cycle. It is meant the electrode have bad intercalation process due to its crystallinity problem [10]. Furthermore, the electrode quality can be affect the inserting process of lithium ion and number cycles of reversible process of this coin cell. Based on the CV measurement results are needed further improvement in anode fabrication.

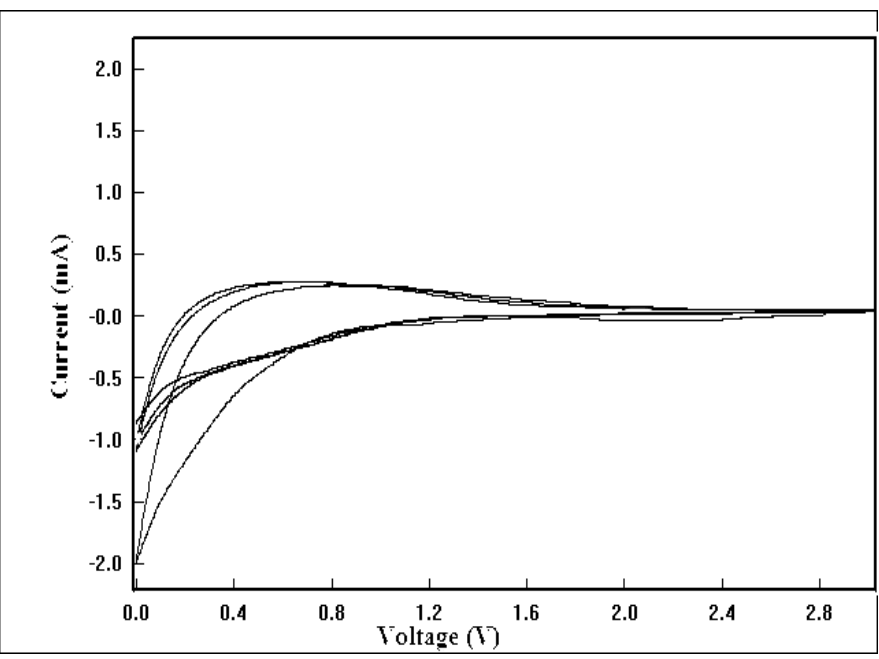

Fig. 3. Voltammogram CV of Coin Cell

\section{Results of CD Measurement}

The charge-discharge performance had been measured and displayed at figure 4 . The first stage of this measurement is to discharge this coin cell. At the end of discharging process, it has specific capacity $200 \mathrm{mAh} / \mathrm{g}$ on voltage $0.5 \mathrm{~V}$. The second stage is to do charging process and at the end this process shows it has specific capacity $180 \mathrm{mAh} / \mathrm{g}$ on voltage $3.0 \mathrm{~V}$. And the third process is discharging process, it has specific capacity $400 \mathrm{mAh} / \mathrm{g}$ on voltage $2.4 \mathrm{~V}$.

This coin cell has specific capacity performance as good as previous finding researchers [10-11]. It had an effective charging but still had a serious problem in the rapid discharging process. So it would need the improvement of electrode's quality in the next research 


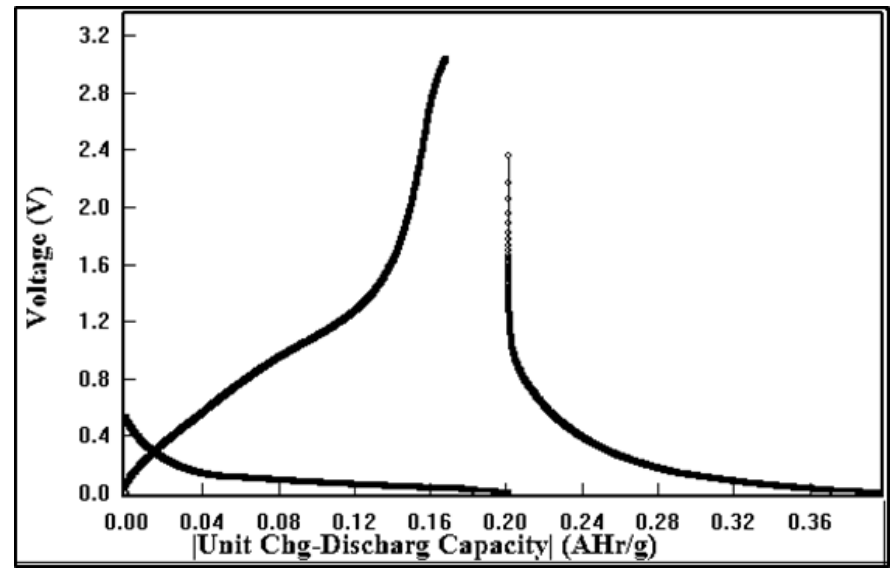

Fig. 4. Charge-Discharge Plot of Coin Cell

The performance of the coin cell is very dependent on the anode materials. As the findings of the researchers [11-14] are summarized in Table I. It can be understood that the anode made of rGO has the highest value specific capacity in the discharging process $(400 \mathrm{mAh} / \mathrm{g})$ and has a good capacity in the charging process $(180 \mathrm{mAh} / \mathrm{g})$. Specific capacity constraints in charging processes require special treatment in the fabrication of the anode, i.e. using the rGO-graphite composite with certain composition.

TABLE I. SPECIFIC CAPACITY DIFFERENCE OF VARIETY ANODE MATERIAL

\begin{tabular}{|l|c|c|}
\hline \multirow{2}{*}{\multicolumn{1}{|c|}{ Anode }} & \multicolumn{2}{|c|}{$\begin{array}{c}\text { Specific Capacity } \\
(\mathbf{m A h} / \mathbf{g})\end{array}$} \\
\cline { 2 - 3 } & $\begin{array}{c}\text { Charging } \\
\text { Process }\end{array}$ & $\begin{array}{c}\text { Discharging } \\
\text { Process }\end{array}$ \\
\hline graphit & 301 & 253 \\
\hline rGO & 180 & 400 \\
\hline graphit coated $\mathrm{Na}_{2} \mathrm{CO}_{3}$ & 367 & 316 \\
\hline rGO coated $\mathrm{Na}_{2} \mathrm{CO}_{3}$ & 8 & 18 \\
\hline
\end{tabular}

\section{CONCLUSION}

In this paper, Lithium-Ion coin cell was successfully synthesized and characterized based on $\mathrm{rGO} / \mathrm{Cu}$ composite. It has electrical performances: (1) electrical conductivity $(\sigma)$ value is $8.2 \times 10^{-5} \mathrm{~S} / \mathrm{cm}$, (2) the different peak value of anode and cathode voltage are $1.0 \mathrm{~V}$ for the first cycle and $0.8 \mathrm{~V}$ for the next cycle, and (3) specific capacity $180 \mathrm{~mA} / \mathrm{g}$ (charging) and (discharging).

\section{ACKNOWLEDGMENT}

The authors would like to express their gratitude to Physics Research Center - Indonesian Institute of Science who has facilitated the equipment, research materials, and academic discussion.

\section{REFERENCES}

[1] S.J. An, J. Li, C. Daniel, D. Mohanty, S. Nagpure, and D.L. Wood. "The state of understanding of the lithium-ion-battery graphite solid electrolyte interphase (SEI) and its relationship to formation cycling," Carbon, vol. 105, pp. 52-76, August 2016.

[2] X. Huang, H. Chen, S. Zhou, Y. Chen, J. Yang, Y. Ren, H. Wang, M. $\mathrm{Qu}, \mathrm{Z}$. Pan, and Z. Yu.,"Synthesis and characterization of nano$\mathrm{Li}_{1.95} \mathrm{FeSiO}_{4} / \mathrm{C}$ composite as cathode material for lithium-ion batteries," Electrochimica Acta, vol. 60, pp. 239-24, January 2012.

[3] J.-K. Meng, L. Fu, Y.-S. Liu, G.-P. Zheng, X.-C. Zheng, X.-X. Guan, and J.-M. Zhang., "Gas-liquid interfacial assembly and electrochemical properties of 3D highly dispersed $\alpha-\mathrm{Fe}_{2} \mathrm{O}_{3} @$ graphene aerogel composites with a hierarchical structure for applications in anodes of lithium ion batteries," Electrochimica Acta, vol. 224, pp. 40-48, January 2017.

[4] J.B. Goodenough, K.-S. Park, "The Li-ion rechargeable battery: a perspective," J. Am. Chem. Soc., vol. 135 (4), pp. 1167-1176, January 2013.

[5] D. Mohanty, J. Li, R. Born, L. C. Maxey, R. B. Dinwiddie, C. Daniel, and D. L. Wood, "Non-destructive evaluation of slot-die-coated lithium secondary battery electrodes by in-line laser caliper and IR thermography methods," Anal. Methods, vol. 6 (3), pp. 674, February 2014.

[6] D. Mohanty, A. Huq, E.A. Payzant, A.S. Sefat, J. Li, D. P. Abraham, D. L. Wood, and C. Daniel, "Neutron diffraction and magnetic susceptibility studies on a high-voltage Li1.2Mn0.55Ni0.15-Co0.10O2 lithium ion battery cathode: insight into the crystal structure," Chem. Mater., vol. 25 (20), pp 4064-4070, September 2013

[7] J. Li, B.L. Armstrong, C. Daniel, J. Kiggans, and D.L. Wood, "Optimization of multicomponent aqueous suspensions of lithium iron phosphate (LiFePO4) nanoparticles and carbon black for lithium-ion battery cathodes," J. Colloid Interface Sci., vol. 405, pp. 118-124, September 2013.

[8] A.F. Kurniawan, "Synthesize of Composite Based on Reduced Graphene from Coconut Shell and Zinc Oxide as Supercapasitor Materials," Final Project - SF141501, Institut Teknologi Sepuluh Nopember Surabaya, 2016

[9] H.-P. Liu, G.-W. Wen, S.-F. Bi, C.-Y. Wang, J.-M. Hao, and P. Gao, "High rate cycling performance of nanosized Li4Ti5O12/graphene composites for lithium ion batteries,", Electrochimica Acta, vol. 192, pp. 38-44, February 2016.

[10] S. Liu, B. Shen, Y. Niu, and M. Xu, "Fabrication of $\mathrm{WS}_{2}$ nanoflowers@rGO composite as an anode material for enhanced electrode performance in lithium-ion batteries," Journal of Colloid and Interface Sci., vol. 488, pp. 20-25, February 2017.

[11] S. Komaba, M. Watanabe, H. Groult, and N. Kumagai, "Alkali carbonate-coated graphite electrode for lithium-ion batteries," Carbon, vol. 46, pp. 1184-1193, August 2008.

[12] Ningsih, D. A.; Synthesize of Composite $\mathrm{rGO} / \mathrm{Ca}_{2} \mathrm{CO}_{3}$ as Lithium Ion Battery Anode, Final Project, Universitas Negeri Surabaya, 2017.

[13] Z.A.I. Supardi, Ningsih, Munasir, and B. Prihandoko, "Fabrication of $\mathrm{rGO} / \mathrm{Cu}$ Anode for Lithium Ion Battery, Research Grant of Faculty of Mathemtics and Science, Universitas Negeri Surabaya, 2016.

[14] R. Yazami, Y.F. Reynier, "Mechanism of self-discharge in graphiteelithium anode," Electrochim Acta, vol. 47, pp. 1217-1223, February 2002. 